\title{
Demonstration of the Nearly Zero Energy Building Concept
}

\author{
Marjana Šijanec Zavrl1, Gašper Stegnar1, Henrik Gjerkeš1,2 \\ ${ }^{1}$ Building and Civil Engineering Institute ZRMK, Ljubljana, Slovenia \\ ${ }^{2}$ University of Nova Gorica, Nova Gorica, Slovenia \\ Email: marjana.sijanec@gi-zrmk.si
}

Received 9 May 2015; accepted 20 August 2015; published 25 August 2015

\begin{abstract}
Nearly zero energy buildings (nZEB) will become an obligatory energy efficiency standard in Europe. Following to common guidelines in European legislation, the countries investigated technical and economic framework for the preparation of detailed national technical definition of nZEB. Slovenia accepted the nZEB criteria in early 2015. This paper describes the technical and economic background for identification of economically viable concepts of highly energy efficient apartment building. The highrise demonstration building Eco Silver House revealed that meeting nZEB standards was not an easy task, not so much for technical reasons, but mostly due to the processes, inadequate skills, not fully compliant regulation and insufficient possibilities for interaction between the building and energy networks. Analysis of cost effectiveness showed that the Eco Silver House fulfilled minimal requirements of cost-optimal for apartment building with Net Present Value of $272 \mathrm{EUR} / \mathrm{m}^{2}$ and Primary energy use of $79 \mathrm{kWh} / \mathrm{m}^{2} \cdot \mathrm{a}$ in line with the Slovenian national cost optimal study of minimum energy performance requirements from the year 2014. At the time, the requirement of $50 \%$ share of renewables in final energy use is not fulfilled, but will be easily reached when EU2020 energy efficiency targets set in the Slovenian Energy Act regarding the RES share in district heating systems and public power grid will be gradually implemented. The demonstration project FP7 EE-HIGHRISE confirms that in spite of the barriers, the nZEB minimum requirements defined on profound theoretical studies can be met in practice.
\end{abstract}

\section{Keywords}

Nearly Zero Energy Building, Demonstration Project, Cost-Optimal, Highrise

\section{Introduction}

Slovenia is a country with 2 million population relatively evenly dispersed in almost 6000 settlements distributed over the territory of $20,000 \mathrm{~km}^{2}$. About seventy settlements are ranked as towns and cities, and from them only the two largest cities have more than 100,000 inhabitants. Altogether 950,000 people live in urban areas and another 400,000 inhabitants live in suburban settlements in vicinity, the rest of population live in rural area [1]. In the period 2010-2013 the average growth of population is 1.7 persons per 1000 inhabitants. Settling pattern and demography influence the typology of the national residential building stock and its growth. In Slove- 
nian residential buildings, $73 \%$ of useful floor area belongs to single family houses and 27\% to apartment buildings. The average annual number of building permits varies from 4000 to 6000 , and up to $15 \%$ of them are issued for apartment buildings [2].

In spite of the fact that the majority of new residential buildings are single family houses, the construction of apartment buildings offers better opportunity to demonstrate new concepts of nearly zero energy buildings (nZEB) and to activate replication potential among other developers as well as among future private homeowners. Therefore, this paper is focused on identification of economically viable concepts of highly energy efficient apartment building leading to ambitious climate and energy targets defined for the Slovenian residential sector.

The 2050 vision is oriented towards almost zero-carbon building stock that shall be reached by considerable improvement of energy efficiency of buildings, i.e. in average 50\% reduction of energy demand with respect to 2005 status, and by almost 100\% energy supply from renewable energy. The indicative targets for year 2030 comprise 15\% reduction of final energy use in building sector with respect to 2005 situation, at least 32\% share of renewables in final energy use for heating and cooling, as well as 66\% reduction of greenhouse gases (GHG) with respect to the base year 2005. In order to meet these targets deep energy renovation of around $40 \%$ of the building stock will be needed. This includes over 9 million of residential buildings and 3.6 million of tertiary buildings that shall be intensively renovated in a way to meet nearly zero energy building standard. In line with EU legislation all new building will have to meet nZEB criteria from the end of 2020 on, while new public buildings have to comply with nZEB standard two years earlier, i.e. from the end of the year 2018.

The operative targets in Slovenia set for the year 2020 comprise 11\% reduction of final energy in buildings, $31 \%$ share of renewables in final energy for heating and cooling in buildings and 53\% reduction of GHG for a base year 2005. Deep renovation of existing buildings shall create a necessary shift towards more energy efficient building stock. However, focus on innovative solutions for early nZEB buildings, new and renovated, will create a necessary technological development, skilled professionals and contractors as well as informed investors and clients for further deployment of more sustainable building sector [3] [4].

Different policies and instruments (advanced building regulation, subsidies, trainings, advisory, information and awareness raising programs, demonstration projects) are available in the country to facilitate the implementation of early nZEB buildings, as by the year 2020 (2018) when nZEB becomes a legal obligation over 0.6 million $\cdot \mathrm{m}^{2}$ of $\mathrm{nZEB}$ buildings shall be constructed on a voluntary basis.

\section{Cost Effective and Cost Optimal Minimum Requirements}

\subsection{Methodology}

European legislation EU Directive 31/2010/EU on energy performance of buildings (revision) (Directive EPBD) [5] requires all new buildings to meet higher levels of performance than before, by exploring more the alternative energy supply systems available locally on a cost-efficiency basis and without prejudicing the occupants' comfort. More in detail the national building codes have to correspond to the cost-optimal level. Advanced highly energy efficient buildings must be defined in technical terms in order to represent national nZEB standard as well as policies and instruments have to be developed to facilitate the early construction in nZEB before the legal obligation will be fully put in place (in the year 2020 and 2018 for public buildings, respectively).

The energy efficiency measure can be considered as a cost effective if the pay-back period of the measure is shorter than its life time. Usually the energy concept of the advanced energy efficient building is composed of a number of measures and thus the impact of the whole set of interventions is compared with the reference building concept, corresponding to the minimum acceptable energy performance standard.

Directive EPBD has imposed the whole life cycle costs as a criterion for economic assessment of the building energy concept, while the building energy performance is presented with the annual primary energy needed for maintenance of thermal conditions, Figure 1. Current minimum requirements are usually too loose to meet the ambitious energy performance standards, therefore such buildings have high primary energy use and high whole life cycle costs, expressed by net present value (NPV). An energy concept of a building with better energy performance and with lower discounted costs of investment, maintenance, replacement and energy costs during the operation phase is considered as a cost effective; however, the optimal concept is the one with minimum NPV of whole life cycle costs.

By the European regulation the gap between the cost-optimal level of energy performance minimum requirements and the threshold in national building codes may not exceed 15\%. Also an indication is given for the 


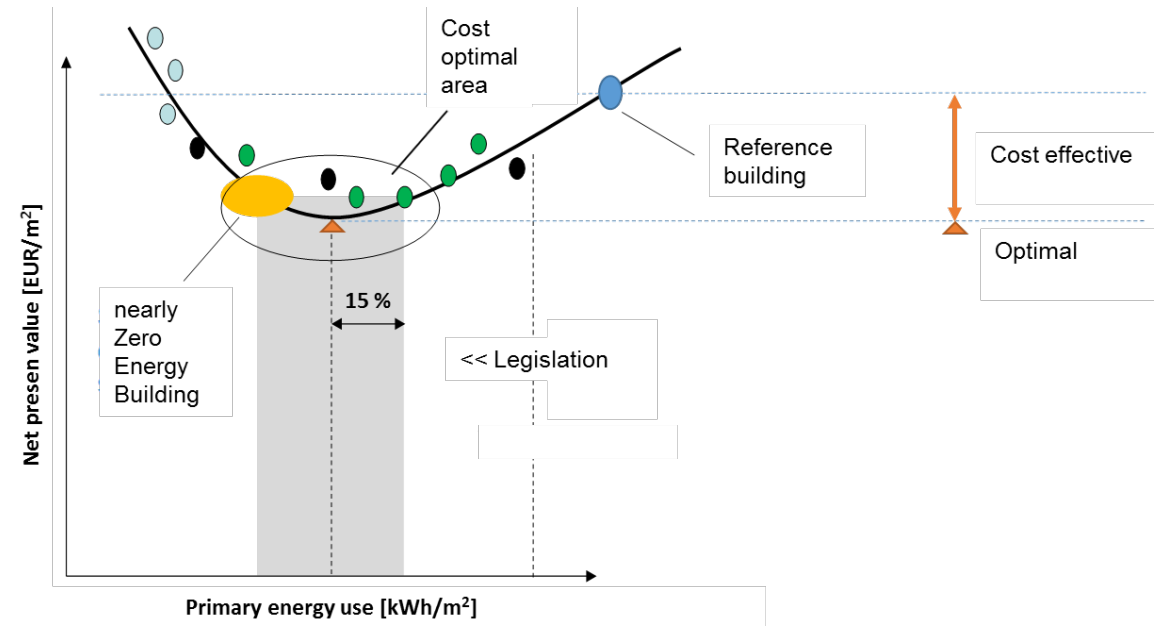

Figure 1. The principle of cost effective and cost-optimal energy design of a building (adapted from [5]).

nZEB minimum requirements, i.e. an energy concepts of a highly energy efficient building is considered acceptable if its primary energy indicators is approx. $10 \%$ lower of the cost-optimal benchmark. Consequently, this is considered as a starting point for national technical definition of nZEB, taking into consideration the fact that by the deadline for the full implementation of nZEB in the year 2020 the costs of energy efficiency measures and technologies for the use of renewables on the building of nearby will become more affordable and cost effective and closer to the cost-optimal benchmark.

\subsection{The Gap of Slovenian Building Codes}

European legislation states that European Union member states must ensure that minimum energy performance requirements for buildings are set with a view to achieving cost-optimal levels according to the Commission Delegated Regulation (EU) No 244/2012 of 16 January 2012 [6]. The conclusions from Slovenian national cost optimal study of minimum energy performance requirements from the year 2014 showed that for new buildings the gap between the calculated cost-optimal levels of minimum performance requirements and those in force in the regulation from 2010 is $-14 \%$. The evaluation of the gap was done based on the financial perspective relevant for the investor and the primary energy as a performance indicator. 2015 revision of the regulation will have to remove the identified minor inconsistencies.

The calculation of cost optimal levels of minimum requirements was done for various reference buildings representing typical building stock in Slovenia, i.e. for two types of a single family house (small and big), apartment building, non-residential/office public building and two alternatives of a non-residential/commercial building (less and more glazing in the envelope). The revision of the national energy efficiency building codes in 2015 shall consider the findings of cost optimal study and improve minimum requirements in a way to make a smooth transition between 2010 level and nZEB minimum requirements.

\section{Definition of Nearly Zero Energy Building}

\subsection{European Legislation}

European legislation Directive EPBD requests all new buildings to meet higher levels of performance than before, by exploring more the alternative energy supply systems available locally on a cost-efficiency basis and without prejudicing the occupants' comfort [7]. After 2020, all new buildings should become "nearly zeroenergy" and after 31 December 2018, the same requirement is applied for new buildings occupied and owned by public authorities.

Technical definitions in the countries differ significantly [8] [9]. As nZEB means a building that has a very high energy performance, this requirement is described either by energy need for heating and cooling or by any other indicator of energy efficiency, e.g. energy class from the energy performance certificate. 
The nearly zero or very low amount of energy required should be covered to a very significant extent by energy from renewable sources, including energy from renewable sources produced on-site or nearby. This part of the legislative statement is transposed to the national regulations by the primary energy indicator and by the share of renewable energy in the total energy use of the building, respectively.

The renewable energy sources (RES) considered in the building energy performance is the most important element for meeting nZEB technical requirements. Traditionally, RES are integrated in the primary energy balance if energy from RES is produced at the building level. European countries accepted different solutions for consideration of RES being used at a building level, on-site, nearby or even in the national grid [10] [11]. European (CEN) and international (ISO) standards are in preparation in order to give a more unique methodology for RES consideration [12].

\subsection{National nZEB Criteria}

Slovenia implemented the EPBD recast based minimum requirements for energy-efficient buildings in 2010 Building Codes. In the 2008 Regulation (PURES 2008), an intensive reduction of transmission losses through the building envelope, as well as new requirements on the obligatory $25 \%$ use of renewable energy sources in the final energy use, were introduced. The 2010 Building Codes (PURES 2010) built on 2008 version and placed the focus also on the calculation of primary energy and $\mathrm{CO}_{2}$ indicators, set additional minimum requirements for the primary energy for heating, limited the heating and cooling needs, both in terms of useful and primary energy, and added many new minimum requirements for energy systems.

The minimum requirements at the end of 2014, in line with the recast EPBD, were defined in the revised Regulation on the efficient use of energy in buildings (PURES 2010), applied on a voluntary basis since July 2010, and fully in force since January 2011. From January 2015 on more severe minimum requirements for maximum energy needs for heating have entered into force according to the long term perspective integrated in the rules of PURES 2010 Building Code. Minimum requirements are expressed using performance-based requirements, energy-related requirements, and detailed technical requirements for building components and systems. In 2015 the Building Codes will be revised with respect to the outcome of cost optimal study and amended with further details accompanying national definition of nZEB and upgraded with complemented according to nZEB details.

Climate in Slovenia is typical for central Europe as shown by the distribution of degree-days on a map, Figure 2, the estimate for the distribution of energy consumption for heating. Climate in Slovenia is determined

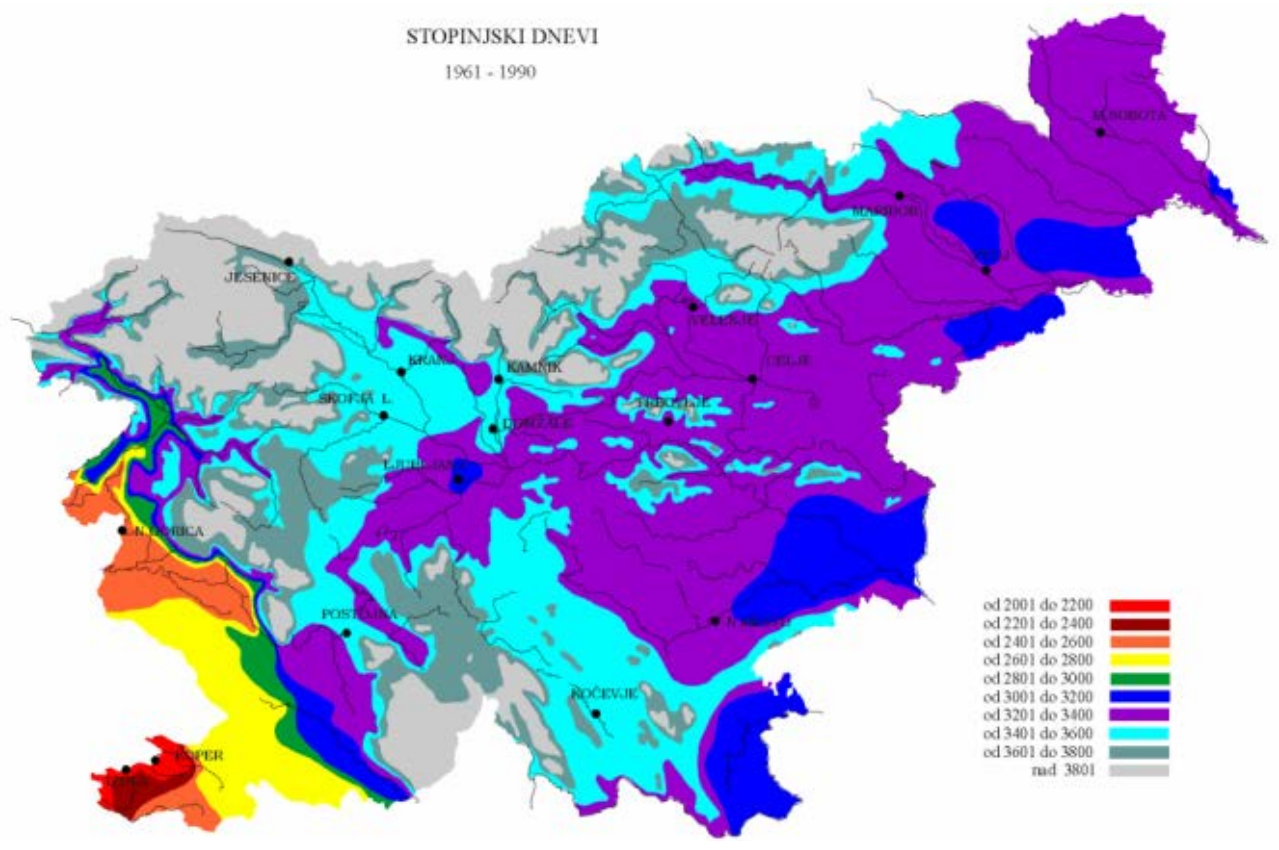

Figure 2. Spatial distribution of degree-days in Slovenia [13]. 
by many factors, the most important are its geographic location, diverse terrain, the orientation of mountain ridges and proximity to the sea. The result of many intertwined factors is a very diverse climate. Thus, there are three predominant types of climate in certain areas but their effects are intertwined: in eastern Slovenia has a temperate continental climate in central Slovenia sub-Alpine (Alpine in the mountains) and west of the Dinaric-Alpine barrier sub-Mediterranean climate. Over $90 \%$ of inhabitants live in the regions with more than 2800 degree days.

The national definition of nZEB was formulated [4] [14] [15] based on the cost-optimal study of minimum energy efficiency requirements [16], with consideration to building tradition, availability of technologies for nZEB and with respect to the Slovenian climate.

National definition of nZEB is based on cost optimal study for reference buildings where the primary energy as a core nZEB performance indicator is complemented with the criterion of achievable target of $50 \%$ share of renewables in final energy use, selected with consideration to the nZEB acceptable technologies and available renewable energy sources. In future the use of RES will be increased due to growing share of RES in district heating systems that are subject to comply with 2020 energy efficiency targets set in the Energy Act. In addition to that, the nearly zero or very low amount of energy required is achieved by further limitation of energy need for heating to a maximum value between $25 \mathrm{kWh} /\left(\mathrm{m}^{2} \mathrm{~K}\right)$ and $15 \mathrm{kWh} /\left(\mathrm{m}^{2} \mathrm{~K}\right)$, with respect to the shape factor and climate on the location. Although not directly prescribed the very high energy performance of nZEB will be demonstrated with nZEB building ranked in class A1, A2 or B2 based on the building heating needs.

nZEB definition provided minimum requirements for primary energy (for all energy use according to Directive EPBD Annex I, including lighting in residential building and excluding appliances and other energy use but EPBD related.) for new building as well as for major renovation, for single family houses, apartment buildings and for non-residential/office buildings. nZEB action plan with the national definition of nZEB was accepted by the government in April 2015.

\section{Case Study Eco Silver House}

Eco-Silver House (ESH) is a multi-residential highrise building located in the city center of Ljubljana, Slovenia (Figure 3). It is part of FP7 EE-Highrise demonstration project, aiming to demonstrate new nearly zero energy building (nZEB) technologies, integrated design concept, systems for sustainable, nZEB construction in order to test and assess the technological and economic feasibility of innovative energy solutions in the highrise multiresidential building (www.ee-highrise.eu). ESH has been designed as two rays forming a shape of an inverted letter " $L$ ". The net total area covers a surface of $23.455 \mathrm{~m}^{2}$ in 17 floors $\left(12.870 \mathrm{~m}^{2}\right.$ net conditioned residential area in 128 flats). The building is a private investment built for the market and its concept aims to correspond to the specific needs of potential buyers, looking for intelligent, eco-oriented passive building.

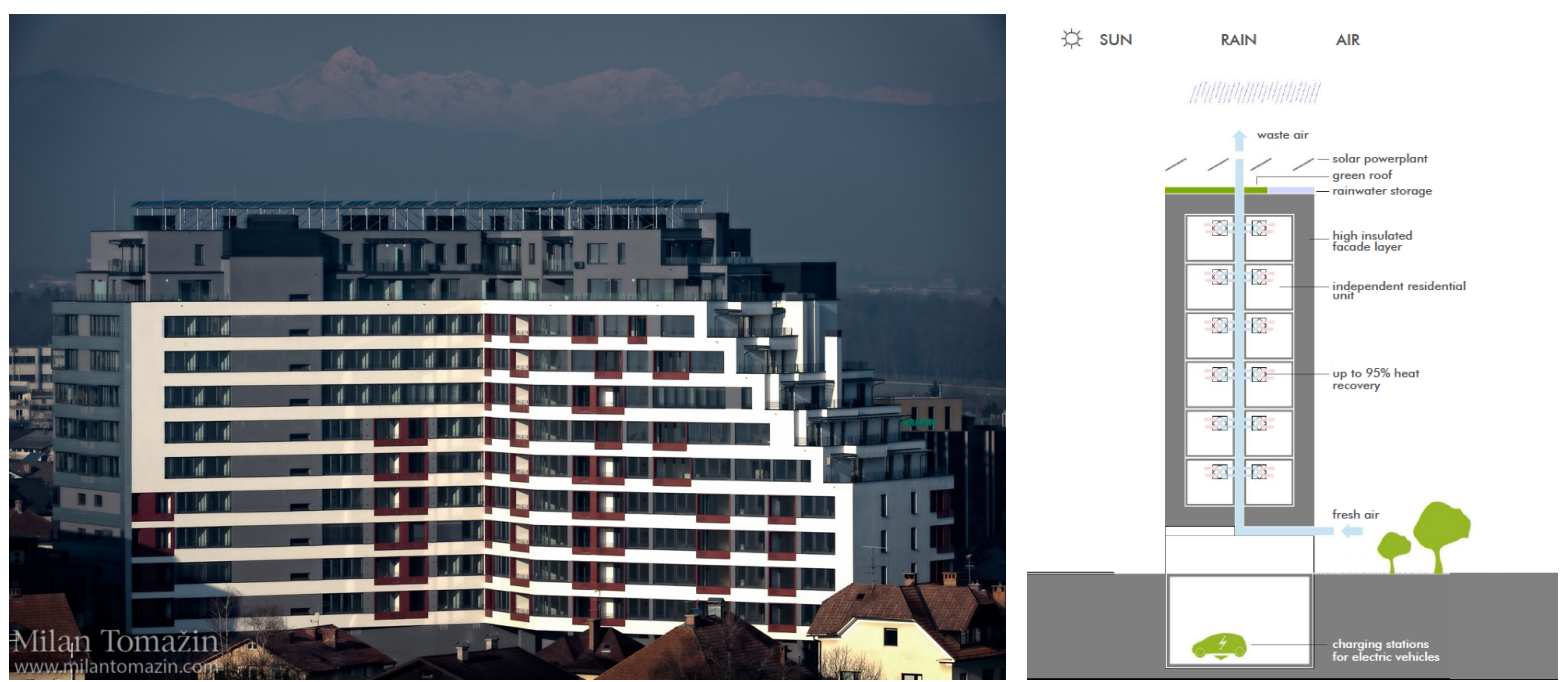

Figure 3. Eco Silver House-design concept and a completed demonstration passive building (Photo: Milan Tomazin, Design: Akropola). 
The energy concept of the building allows cost-independent performance of apartment units where good insulation of thermal envelope and dynamic shading as well as the possibility of individual (intelligent) control of indoor conditions ensure that each apartment can function like an independent passive house. The $U$ value of the building envelope varies between $0.17 \mathrm{~W} /\left(\mathrm{m}^{2} \mathrm{~K}\right)$ (walls) and $0.14 \mathrm{~W} /\left(\mathrm{m}^{2} \mathrm{~K}\right.$ ) (roof), while the $\mathrm{U}$ value of triple glazed $\left(\mathrm{Ug}=0.58 \mathrm{~W} /\left(\mathrm{m}^{2} \mathrm{~K}\right)\right.$ window of standard dimensions is $0.83 \mathrm{~W} /\left(\mathrm{m}^{2} \mathrm{~K}\right)$. The measured airtightness level of the building sectors, $\mathrm{n} 50$, is between $0.45 \mathrm{~h}^{-1}$ and $0.59 \mathrm{~h}^{-1}$ (Blower door test), i.e. bellow the design value of $\mathrm{n} 50=0.6 \mathrm{~h}^{-1}$. The building is connected to the energy efficient municipal district heating, with wood biomass co-burning and cogeneration. In addition to the main district heat station each apartment has its own heat substation for space heating and domestic hot water, while electricity is used for operation of mechanical ventilation with heat recovery (system efficiency of 0.85) and for an inverter heat pump, air to air, for preheating or precooling of the inlet air. The heat is emitted via radiators and partly via floor heating (in bigger apartments). Cooling needs are negligible in standard usage profile. On special request and depending on the particular usage pattern, a multi-split air conditioning system can be installed in bigger flats.

The fundamental principles of sustainable design of a highrise building are reflected in the demonstration project through comprehensive planning of energy efficiency features with respect to passive house standard and national nZEB criteria. Among other by utilizing renewable energy sources, very good thermal insulation, highperformance air-conditioning system with heat recovery, dynamic sun protection, intelligent control and management of electric and mechanical devices, machinery and tools, a significant share of ecological materials. Building owners use rainwater stored in a roof tank $\left(60 \mathrm{~m}^{3}\right.$ storage is sufficient for 10-day sanitary water demand and allows $500 \mathrm{~m}^{3}$ of fresh water savings), a micro solar power plant (34 kWp) on the roof, green roof, and e-mobility with car sharing, Figure 4. The building was completed in 2014 and in 2015 entered in post-occupancy monitoring period.

During the design and construction phase the focus of demonstration project was on implementation of integrated energy design and quality assurance (QA) protocols. The scope of the on-going post-occupancy research is monitoring of the energy performance indicators, comfort parameters and users' satisfaction as well as assessment of sustainable building indicators.

\section{Results and Discussion}

Eco Silver House, as built, fulfils the commonly accepted passive house standard characteristics with a PHPP annual heating demand of $14 \mathrm{kWh} /\left(\mathrm{m}^{2} \cdot \mathrm{a}\right)$ and primary energy use for annual heating and cooling $106 \mathrm{kWh} /$ $\left(\mathrm{m}^{2} \cdot \mathrm{a}\right)$. According to the national energy performance certificate ESH is ranked in energy performance class A1 with standard annual heat demand of $8 \mathrm{kWh} /\left(\mathrm{m}^{2} \cdot \mathrm{a}\right)$.

Figure 5 shows total delivered energy $51 \mathrm{kWh} /\left(\mathrm{m}^{2} \cdot \mathrm{a}\right)$ and primary energy $85 \mathrm{kWh} /\left(\mathrm{m}^{2} \cdot \mathrm{a}\right)\left(79 \mathrm{kWh} /\left(\mathrm{m}^{2} \cdot \mathrm{a}\right)\right.$ with consideration of exported energy from PV power plant. ESH presents a new standard of the energy-efficient apartment building in Slovenian construction sector, meeting the new 2015 definition of nZEB in Slovenia, setting the maximum allowed primary energy for apartment buildings to $80 \mathrm{kWh} /\left(\mathrm{m}^{2} \cdot \mathrm{a}\right)$.

Figure 6 shows that the Eco Silver House fulfills minimal requirements of cost-optimal for apartment building for apartment building with Net Present Value of $272 \mathrm{EUR} / \mathrm{m}^{2}$ in line with the Slovenian national cost optimal
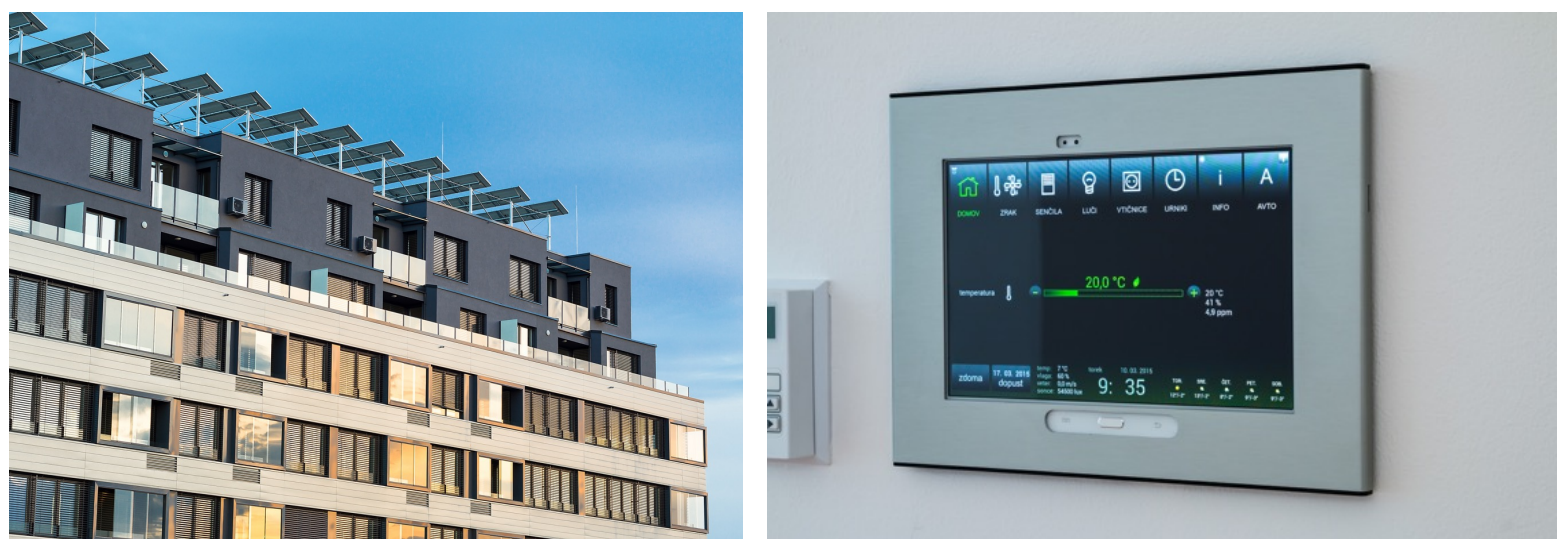

Figure 4. Eco silver house-PV power plant and intelligent control (Photo: borut slabe). 


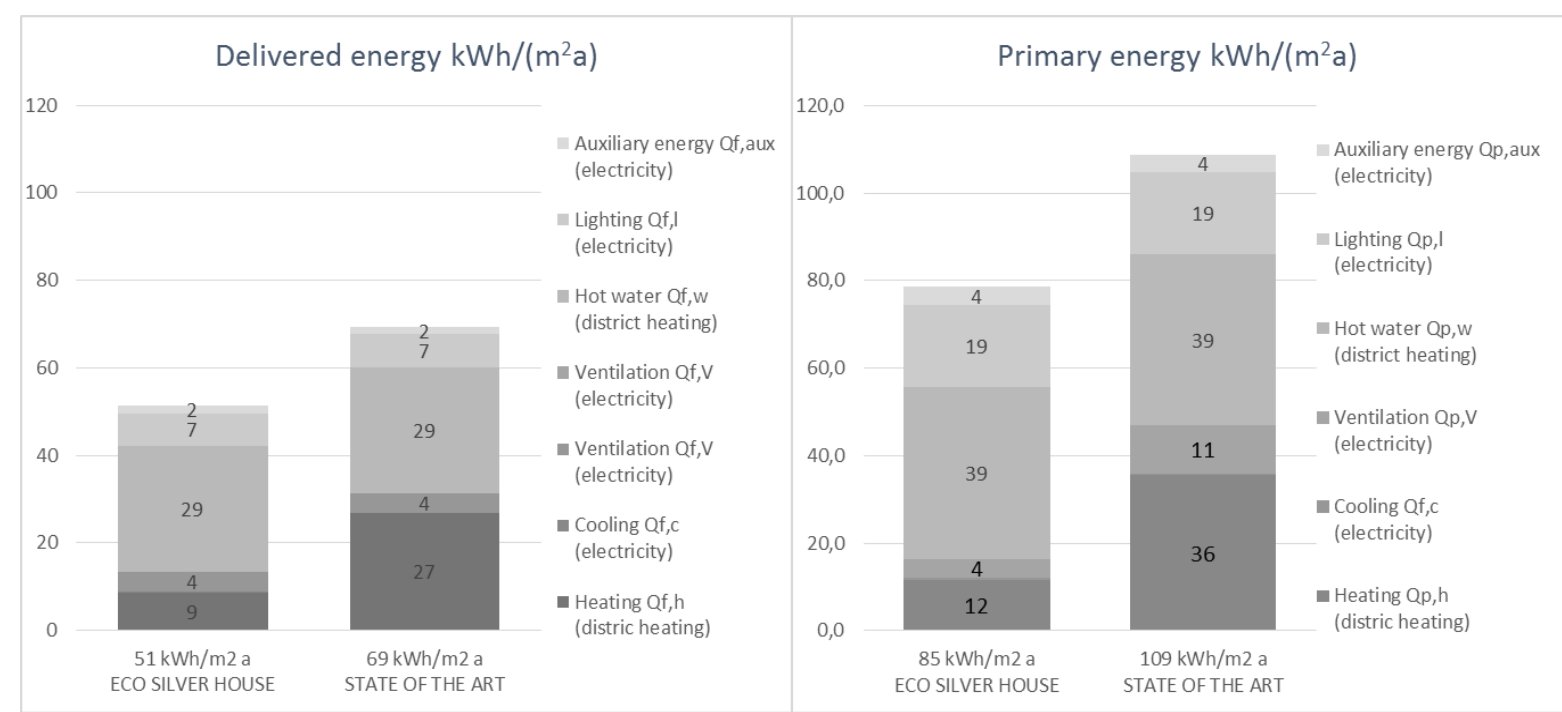

Figure 5. Delivered and primary energy for ESH demonstration building and state of the art new building in Slovenia [19].

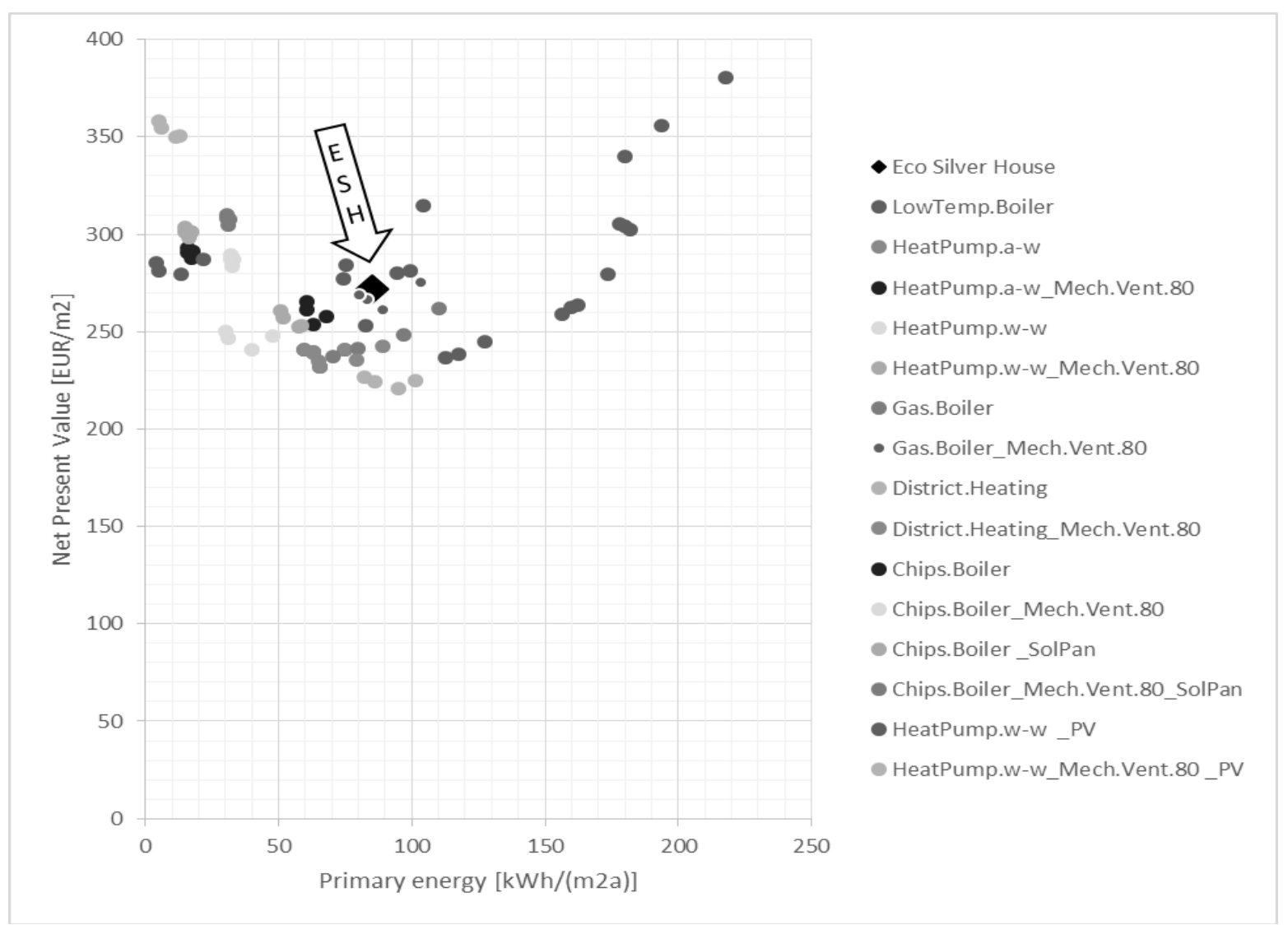

Figure 6. Position of the Eco Silver House (ESH) on the cost-optimal curve for apartment building.

study of minimum energy performance requirements from the year 2014.

The energy performance of the buildings was calculated with IDA Indoor Climate and Energy as a whole year detailed and dynamic multi-zone simulation study of indoor climate and energy use. The minimum energy performance requirements are represented by the area of the cost curve that delivers the lowest cost for the enduser and society. 
National definition of nZEB is complemented with the criterion of achievable target of 50\% share of renewables in final energy use. The Eco Silver House uses two energy sources: heat from the Ljubljana district heating system (DHS) and electricity from the national power grid. Renewable based generation accounted for $9 \%$ of the heat fed into the DHS, which was the result of the wooden biomass co-burning in the heating plant.

The share of RES in power generation on national level is very important for meeting the targets of nZEB and sustainable building. The share of renewables in gross electricity consumption in Slovenia is varying in dependence on economic activity on one side, and hydrological conditions on the other side, as renewable part of power generation originates mainly from large hydro power plants with almost $30 \%$ of national power generation, whereby small qualified producers contribute in average around 5\% [17]. In total power generation in year 2014, the share of RES was 33.5\% [18].

Contribution of both energy sources and total share of RES in final and primary energy balance of the Eco Silver House is presented in Figure 7. In total delivered (Final) energy use of 661 MWh per year, the RES part is $130 \mathrm{MWh}$ from both energy sources. Taking into account the power generation from photovoltaic (PV) power plant on the roof of the Eco silver house of estimated 84 MWh per year, the share of RES in total Final energy is 32.4\%. In total Primary energy use of 1094 MWh per year, the RES part amounts to 484 MWh per year or $44.3 \%$.

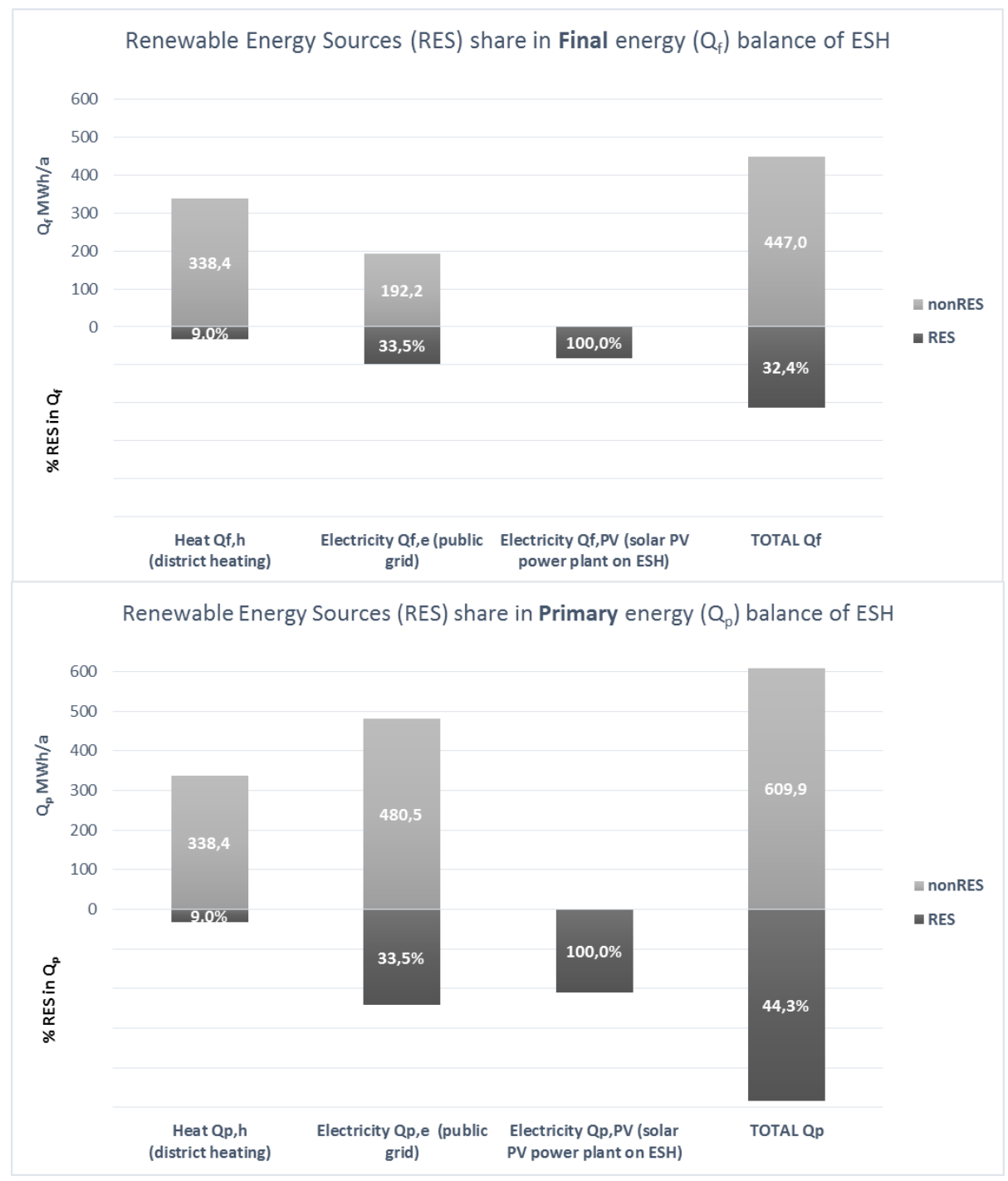

Figure 7. Share of renewable energy sources in final and primary energy balance of Eco Silver House (ESH). 
At the time, the Eco Silver House is not far from, but still does not fulfill requirements of $50 \%$ share of renewables in final energy use. The main obstacle for that is relatively low share of RES in the municipal district heating system. However, the district heating systems are subject to comply with EU2020 energy efficiency targets set in the new Energy Act. Fulfilling the requirements of the Energy Act for district heating systems, together with reaching the target from EU2020 of 39.3\% of RES in electric energy mix by year 2020, the Eco Silver House will easily reach and exceed the nZEB requirements for share of renewables in final energy use.

\section{Conclusions}

From the end of the year 2020 (2018 for public buildings), nZEB energy efficiency standard will have to be fully implemented in all new buildings all over the Europe. The years before the enforcement are to be used to identify the barriers and to get the construction sector ready for the nZEB challenges. Slovenia has officially accepted the national technical definition of nZEB in early 2015. nZEB is a demanding standard, indicating two main challenges in practice. The first challenge is to reach an adequate quality of the works in order to achieve high energy performance of the building and very low energy demand. The second challenge is simply to match the building sector with the energy sector. This is in particular important due to the growing share of renewables in the building energy balance that can only be accomplished if the interaction between the building and the energy networks is taken into consideration for maximum use of RES and the lowest possible primary energy.

The highrise demonstration building Eco Silver House revealed that meeting nZEB standards was not an easy task, not so much for technical reasons, but mostly due to the processes, inadequate skills, not fully compliant regulation and insufficient possibilities for interaction between the building and energy networks.

However, by the demonstration project FP7 EE-HIGHRISE, it is confirmed that in spite of the barriers the nZEB minimum requirements, defined on profound theoretical studies, can be met in practice.

\section{Acknowledgements}

The research presented in this paper is a part of the research and demonstration project FP7 EE-HighriseEnergy efficient demo multi-residential high-rise building supported by the European Commission within the 7th Framework Programme (FP7-2011-NMP-ENV-ENERGY-ICT-EEB) (2013-2015); (www.ee-highrise.eu).

\section{References}

[1] Kladnik, D. (2004) Settling and Settlements. http://zgs.zrc-sazu.si/Portals/8/Slo_Geo_Over/17.pdf

[2] SI-STAT Data Portal. Statistical Office RS.

[3] National Energy Efficiency Action Plan 2020 (NEEAP 2020) for Slovenia (2015).

[4] National Plan to Increase the Number of Nearly Zero Energy Buildings (2015).

[5] Directive 2010/31/EU of the European Parliament and of the Council of 19 May 2010 on the Energy Performance of Buildings (Recast)

[6] Commission Delegated Regulation (EU) No 244/2012 of 16 January 2012

[7] Aelenei, L., et al. (2015) New Challenge of the Public Buildings: nZEB Findings from IEE RePublic_ZEB Project. Energy Procedia, 6th International Building Physics Conference, IBPC 2015, Elsevier, Torino, 14-16 June 2015, in Press.

[8] Marszal, A.J., Heiselberg, P., Bourelle, J.S., Musall, E., Voss, K., Sartori, I. and Napolitano, A. (2011) Zero Energy Building-A Review of Definitions and Calculation Methodologies. Energy and Building, 43, 971-979. http://dx.doi.org/10.1016/j.enbuild.2010.12.022

[9] Aelenei, L., Gonçalves, H., Aelenei, D. (2013) The nZEBs in the Near Future Overview of Definitions and Guidelines towards Existing Plans for Increasing nZEBs. Conference Proceedings of SB13 Guimaraes_Contribution of Sustainable Building to Meet EU 20-20-20 Targets, 2013 SB13, Guimaraes (Portugal) Multicomp 2013, 879-886.

[10] Kurnitski, J., Saari, A., Kalamees, T., Vuolle, M., Niemelä, J. and Tark, T. (2011) Cost Optimal and Nearly Zero (nZEB) Energy Performance Calculations for Residential Buildings with REHVA Definition for nZEB National Implementation. Energy and Buildings, 43, 3279-3288. http://dx.doi.org/10.1016/j.enbuild.2011.08.033

[11] Kurnitski, J., et al. (2013) REHVA nZEB Technical Definition and System Boundaries for Nearly Zero Energy Buildings. REHVA Report No. 4, 2013.

[12] (2014) FprEN 15603: 2014 Energy Performance of Buildings Overarching Standard EPBD. 
[13] Climate of Slovenia (in Slovenian: Klimatografija Slovenije). http://www.arso.gov.si

[14] Šijanec-Zavrl, M., Gjerkeš, H. and Tomšič, M. (2012) Integration of Nearly Zero Energy Buildings: A Challenge for Sustainable Building stock. World Engineering Forum, 17-21 September 2012, Ljubljana, Slovenia. Sustainable Construction for People. Inženirska zbornica Slovenije, Ljubljana

[15] Šijanec-Zavrl, M. and Gjerkeš, H. (2013) Sustainable Energy Networks: A Hub for Nearly Zero Energy Buildings. 3rd International Exergy, Life Cycle Assessment, and Sustainability Workshop \& Symposium (ELCAS-3), Nisyros, 7-9 July 2013, ELCAS-3.

[16] Šijanec-Zavrl, M., Skubic, M., Rakušček, A., Gjerkeš, H. and Potočar, E. (2012) Practical Implementation of CostOptimal Regulation for Establishing National Minimum Requirements of Slovenia. Proceedings of World Sustainable Energy Days, Wels, 29 February-2 March 2012. O. Ö. Energiesparverband, Linz, Wels, 3.

[17] Gjerkeš, H., Šijanec-Zavrl, M. and Stegnar G. (2014) Heat Pumps and Cost Optimal Building Performance. Proceedings of 2nd Annual International Interdisciplinary Conference, AIIC 2014, Vol. 3, Azores, 08-12 July 2014.

[18] IMAD (2014) Institute of Macroeconomic Analysis and Development, Development Report, Indicators of Slovenia's Development.

[19] Šijanec Zavrl, M., et al. (2015) Eco Silver House-A Challenge of Integrated Energy Design and Quality Assurance in Demo EE-Highrise Building. Energy Procedia, 6th International Building Physics Conference, IBPC 2015, Elsevier, Torino, 14-16 June 2015, in Press. 